\title{
Cold emission optimization of a diesel- and alternative fuel-driven $\mathrm{Cl}$ engine
}

\author{
Lukas Nenning $^{1}$ (1) $\cdot$ Helmut Eichlseder ${ }^{1} \cdot$ Michael Egert $^{2}$
}

Received: 10 May 2021 / Accepted: 18 August 2021 / Published online: 9 September 2021

(c) The Author(s) 2021

\begin{abstract}
This paper deals with the emission optimization of a compression ignition (CI) engine during cold ambient operation. Hence, in the present study, the effect of different injector nozzle geometries and pilot injection strategies, but also the influence of intake swirl, rail pressure, exhaust gas recirculation (EGR) as well as EGR cooling on the emission behavior during cold run are investigated. Therefore, test bed experiments under steady-state cold conditions are conducted on a state-of-the-art CI single cylinder research engine (SCRE) with approximately 0.51 swept volume representing the typical passenger car (PC) cylinder size. The cold charge air temperature of down to $-8^{\circ} \mathrm{C}$ and a low engine coolant and lube oil temperature represent a cold run close to reality. For emulating the higher friction of a typical 4-cylinder PC engine during cold run, the indicated mean effective pressure (IMEP) is increased according to a specifically developed equation and the turbocharger main equation is solved permanently to adjust the gas exchange loss. To take account of a potential future tightening of emission legislation, in addition to limited exhaust gas emissions, non-limited emissions such as carbonyls are measured as well. Since alternative fuels are able to make a significant contribution to the defossilisation of transportation, an oxygencontaining fuel, consisting of $100 \%$ renewable blend components (HVO, ethers and alcohols) and fulfilling the EN 590 legislation is investigated under the same cold conditions in addition to the research on conventional diesel fuel.
\end{abstract}

Keywords Cold emission behavior $\cdot \mathrm{CI}$ engine $\cdot$ Combustion optimization $\cdot$ Injector nozzle geometry $\cdot$ Carbonyls $\cdot$ Alternative fuel

$\begin{array}{ll}\text { List of symbols } \\ \Delta \eta_{\mathrm{GE}} & \text { Gas exchange loss } \\ \Delta \eta_{\mathrm{IC}} & \text { Imperfect combustion loss } \\ \Delta \eta_{\mathrm{M}} & \text { Friction loss } \\ \Delta \eta_{\mathrm{RC}} & \text { Real combustion loss } \\ \Delta \eta_{\mathrm{WH}} & \text { Wall heat loss } \\ \eta & \text { Efficiency } \\ \lambda & \text { Excess air ratio } \\ m & \text { Mass } \\ p & \text { Pressure }\end{array}$

Lukas Nenning

nenning@ivt.tugraz.at

Helmut Eichlseder

eichlseder@ivt.tugraz.at

Michael Egert

michael.egert@avl.com

1 Institute of Internal Combustion Engines and Thermodynamics, Graz University of Technology, Graz, Austria

2 AVL List GmbH, Graz, Austria

$\begin{array}{ll}t & \text { Time } \\ T & \text { Temperature } \\ \varphi & \text { Angle } \\ \varphi_{\mathrm{CV}} & \text { Degree of constant volume } \\ x_{\mathrm{B}} & \text { Cumulative heat release }\end{array}$

Abbreviations

$\begin{array}{ll}\text { AD } & \text { Acetaldehyde } \\ \text { BMEP } & \text { Break mean effective pressure } \\ \text { BTE } & \text { Break thermal efficiency } \\ \text { CA } & \text { Crank angle } \\ \text { CI } & \text { Compression ignition } \\ \text { CNL } & \text { Combustion noise level } \\ \text { CO } & \text { Carbon monoxide } \\ \mathrm{CO}_{2} & \text { Carbon dioxide } \\ \text { EAR } & \text { Excess air ratio } \\ \text { EAS } & \text { Exhaust aftertreatment system } \\ \text { EGR } & \text { Exhaust gas recirculation } \\ \text { FA } & \text { Formaldehyde } \\ \text { FMEP } & \text { Friction mean effective pressure } \\ \text { HP } & \text { High pressure } \\ \text { HVO } & \text { Hydrated vegetable oil }\end{array}$




$\begin{array}{ll}\text { ID } & \text { Ignition delay } \\ \text { IMEP } & \text { Indicated mean effective pressure } \\ \text { MFB } & \text { Mass fraction burned } \\ \mathrm{NO}_{\mathrm{x}} & \text { Nitrogen oxide } \\ \text { OME } & \text { Oxymethylenether } \\ \mathrm{PC} & \text { Passenger car } \\ \text { RDE } & \text { Real driving emission } \\ \text { ROHR } & \text { Rate of heat release } \\ \text { SCRE } & \text { Single cylinder research engine } \\ \text { SN } & \text { Smoke number } \\ \text { SOI } & \text { Start of injection } \\ \text { TC } & \text { Turbocharger } \\ \text { TP } & \text { Tailpipe } \\ \text { Subscripts } \\ 20 & \text { Charge air } \\ 21 & \text { Intake manifold } \\ 31 & \text { Engine-out } \\ 32 & \text { Damping vessel } \\ \text { AFC } & \text { Air fuel cycle with real charge } \\ \text { Amb } & \text { Ambient } \\ \text { cum } & \text { Cumulated } \\ \text { CYL } & \text { Cylinder } \\ e & \text { Effective } \\ i & \text { Indicated } \\ \text { Veh } & \text { Vehicle }\end{array}$

\section{Introduction}

The introduction of the real driving emission (RDE) legislation, featuring city, extra-urban and highway driving [1], poses additional challenges for all car manufacturersbesides the achievement of $\mathrm{CO}_{2}$ fleet target values [2]: the permitted option of starting an RDE test at cold ambient temperatures down to $-7^{\circ} \mathrm{C}$ [1], demands higher efforts to comply with emission limits due to increased engine friction as well as higher pollutant emissions [3-5] caused by unfavorable ignition conditions. In the time between the cold start and the EAS reaching its operation temperature to achieve sufficient conversion efficiencies, low engine-out emissions are crucial for adhering to emission limits.

Figure 1 illustrates the $\mathrm{NO}_{\mathrm{x}}$ tailpipe (TP) emissions of an RDE test recorded at moderate ambient temperature. As a result of the cold aftertreatment system and, therefore, nonexistent emission conversion, $17 \%$ of all $\mathrm{NO}_{\mathrm{x}} \mathrm{TP}$ emissions of this test are emitted in only $100 \mathrm{~s}$. Hence, this interval, which is expected to become even more pronounced at lower ambient temperatures, defines the emission behavior of interest.

Internal engine measures should, therefore, ensure both, low engine-out emissions and a fast EAS light-off. These conflicting demands require a precisely optimized

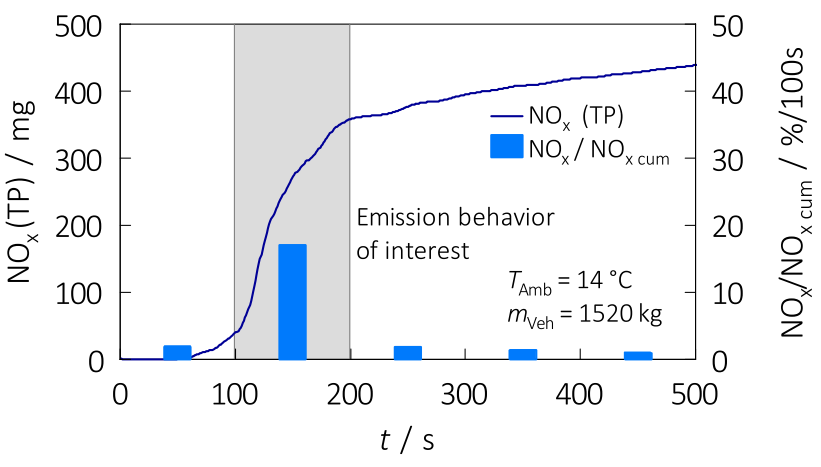

Fig. 1 Emission behavior of a cold-started RDE test

combustion system and underline the need of a holistic approach. To achieve a rapid engine and EAS warm-up several approaches can be applied: Internal measures such as valve train variabilities with an early exhaust valve opening [6] or an intake valve re-opening [7] help to increase the exhaust gas temperature during cold run. Furthermore, the use of thermal barrier coatings and dedicated combustion modes contribute to a faster engine warm-up [8,9]. Thermal measures as for instance a variable coolant flow, split cooling circuits, a lubricant flow diversion or a preheated coolant as well as external measures as an electrically heated catalyst shorten the time until the EAS reaches the light-off temperature and hence improve the cold emission behavior $[8,9]$. In the present study, however, directly combustion related parameters, both on combustion hardware as well as calibration side are investigated.

\section{Methodology}

The comprehensive approach for the investigation of the cold emission behavior of the CI engine is shown in Fig. 3 . Starting with the basics of cold engine operation, the optimization of the pilot injection strategy and the influence of swirl and rail pressure were worked out. Subsequently, effects of different injector nozzle hole diameters and different hole numbers were researched with the SCRE illustrated in Fig. 2.

As demonstrated by numerous studies [10-19], an alternative, non-fossil fuel in a $\mathrm{CI}$ engine can improve the emission behavior compared to diesel. Therefore, such a fuel blend was investigated under cold conditions with the optimum injector design. The experimental results were analysed with a $0 \mathrm{~d}$ combustion analysis to gain a profound understanding of the emission behavior. 


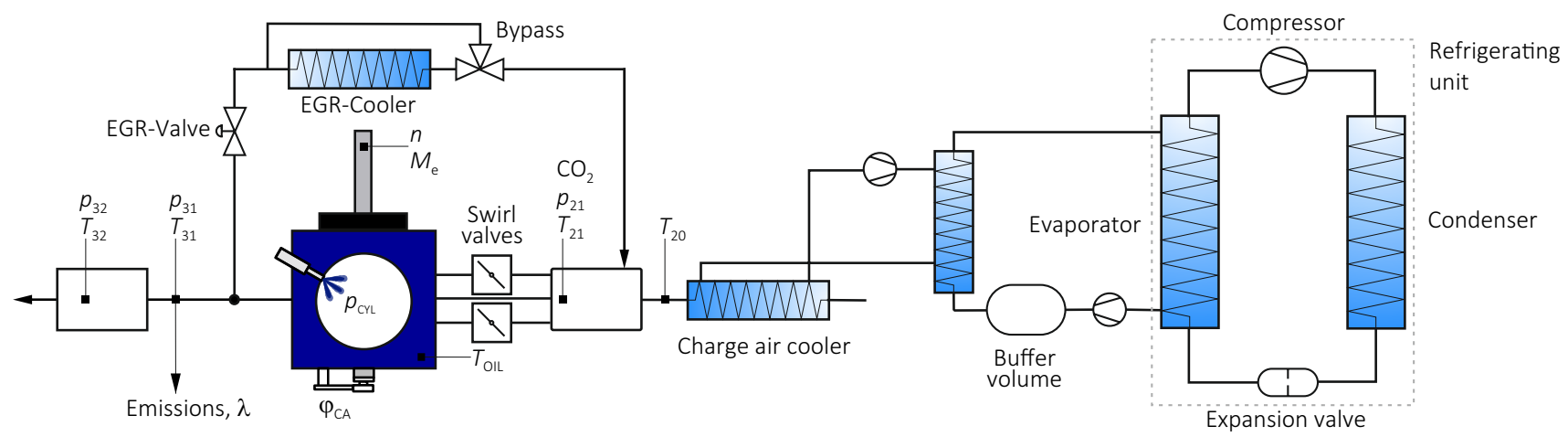

Fig. 2 Schematic of the SCRE measurement setup and the refrigerating unit

\subsection{Test engine}

All the experimental work was carried out on a state-of-theart SCRE with about 0.51 swept volume representing the typical PC cylinder size, which is illustrated in Fig. 2. The technical data of the engine, equipped with the latest fuel injectors, is stated in Table 1 (Fig. 3).

\subsection{Test methodology}

The test runs with the SCRE were carried out maintaining steady-state cold conditions, which offers the possibility of a stationary and reproducible measuring operation. The charge air temperature $T_{20}$ was cooled down to $-8^{\circ} \mathrm{C}$ with a refrigerating unit. The engine coolant and lube oil temperature were about $40^{\circ} \mathrm{C}$. To emulate a full engine operation during cold run as realistically as possible, on the basis of full engine measurements the dependence of the friction mean effective pressure (FMEP) on the lube oil temperature $T_{\mathrm{OIL}}$ was studied. Figure 4 displays the measurement data from different PC engines and the derived formula for the FMEP$T_{\text {OIL }}$ correlation, which was used.

To emulate the gas exchange of a full engine the turbocharger main equation was solved permanently. According to this equation, the exhaust pressure was adjusted by the use of an exhaust flap. To be prepared for future emission legislation, the carbonyls formaldehyde (FA) and acetaldehyde (AD) were measured as well. According to Merker et al. [20], these two components have the largest share of occurring carbonyls in diesel exhaust gas, shown in Fig. 5, and are not legally limited at the moment. In the following the trends of the FA emissions as major representative of the carbonyls are discussed.

\subsection{Validation of methodology}

Figs. 6, 7, 8, 9, 10 present the effects of the applied steadystate cold conditioning methodology at the engine speed of
Table 1 Characteristics of the SCRE

\begin{tabular}{ll}
\hline Type & AVL 5402 \\
\hline Bore & $85 \mathrm{~mm}$ \\
Stroke & $90 \mathrm{~mm}$ \\
Displacement & $511 \mathrm{~cm}^{3}$ \\
Connecting rod & $138 \mathrm{~mm}$ \\
Compression ratio & 15.5 \\
Number of valves & 4 \\
Max. cylinder pressure & 200 bar \\
Max. speed & 4200 min \\
Technology & Common-rail injection system \\
& Bosch CP4.1 fuel pump \\
& Bosch CRI 2-25 injector \\
& Stepped-lip piston bowl \\
& HP-EGR (cooled, with bypass) \\
& Variable swirl system \\
\hline
\end{tabular}

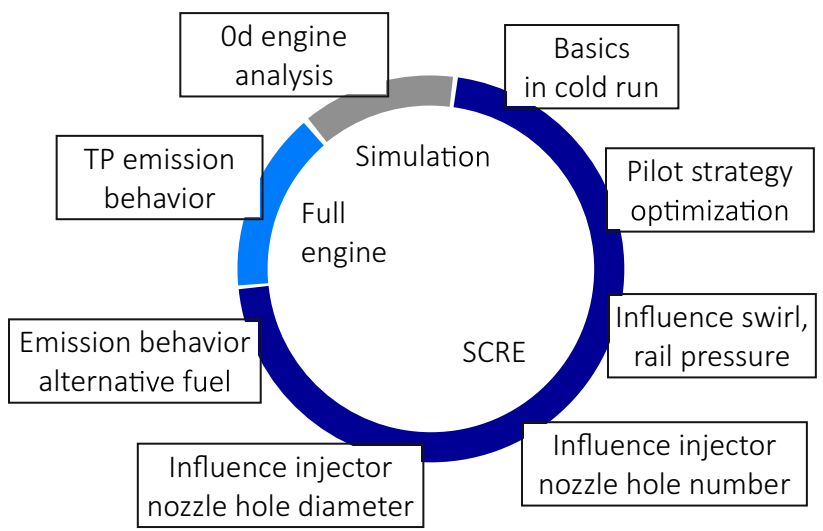

Fig. 3 Methodological approach for cold emission optimization

$2000 \mathrm{~min}^{-1}$ and a constant break mean effective pressure (BMEP) of 6 bar (2000/6bar). 


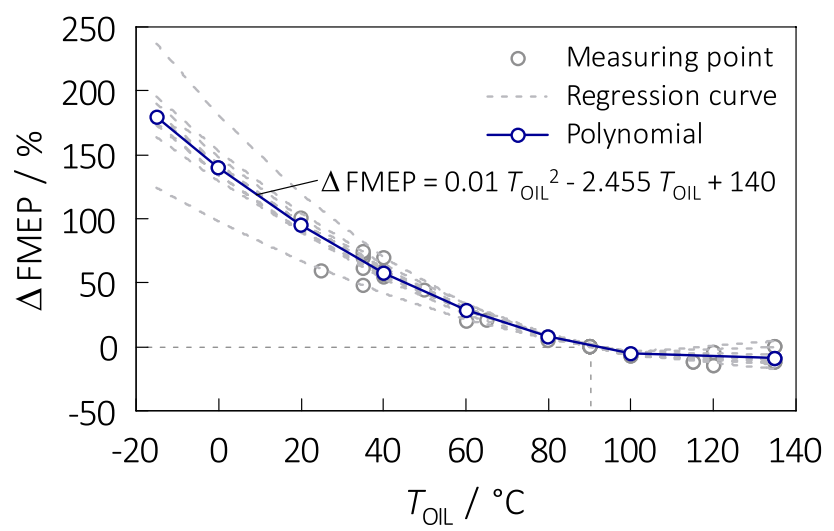

Fig. 4 Oil temperature dependency of FMEP

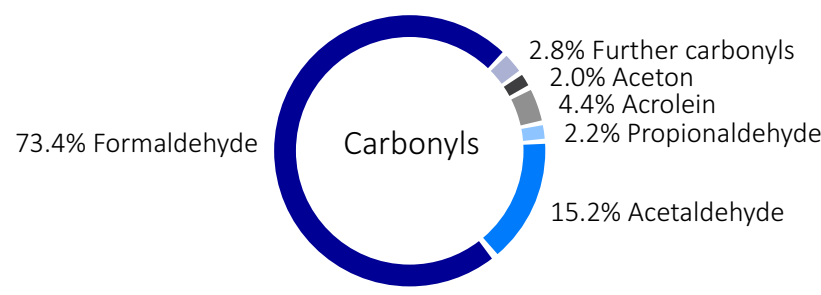

Fig. 5 Distribution of carbonyls in a diesel exhaust gas [20]

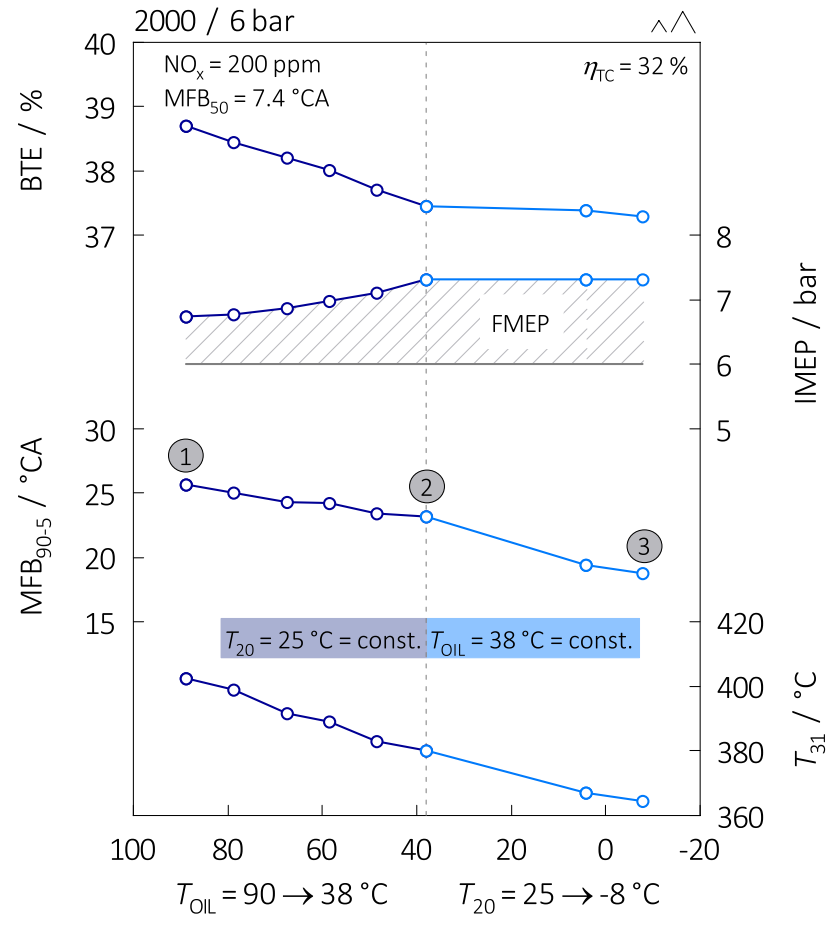

Fig. 6 Combustion behavior of the temperature variation at constant $\mathrm{NO}_{\mathrm{x}}$ emissions (with EGR)

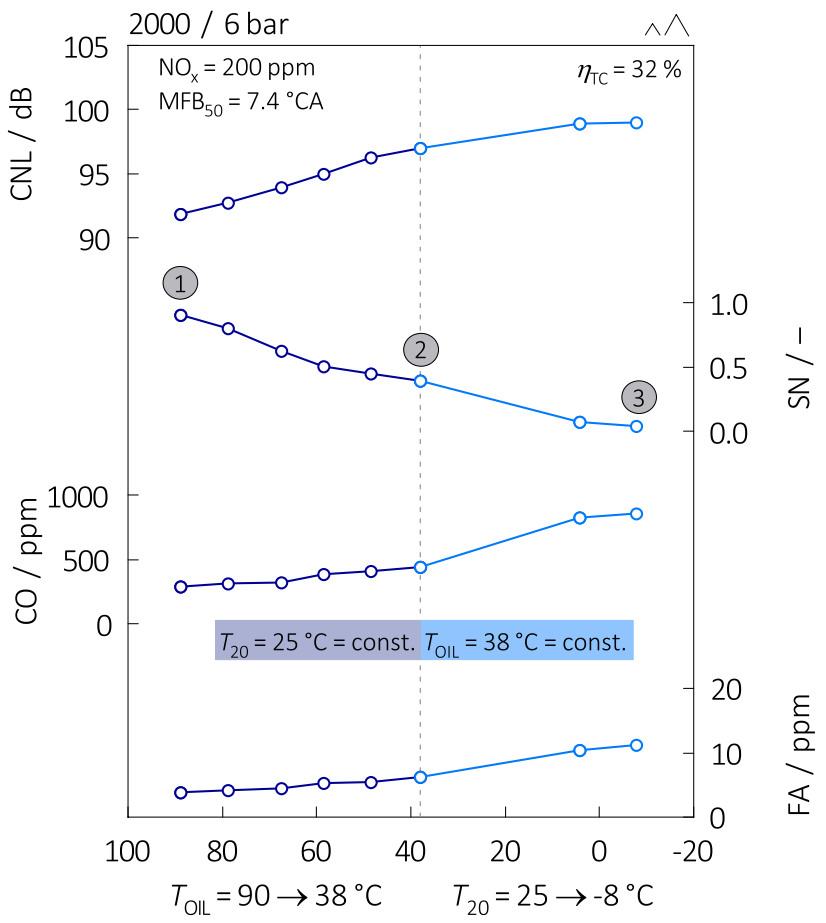

Fig. 7 Emission behavior of the temperature variation at constant $\mathrm{NO}_{\mathrm{x}}$ emissions (with EGR)

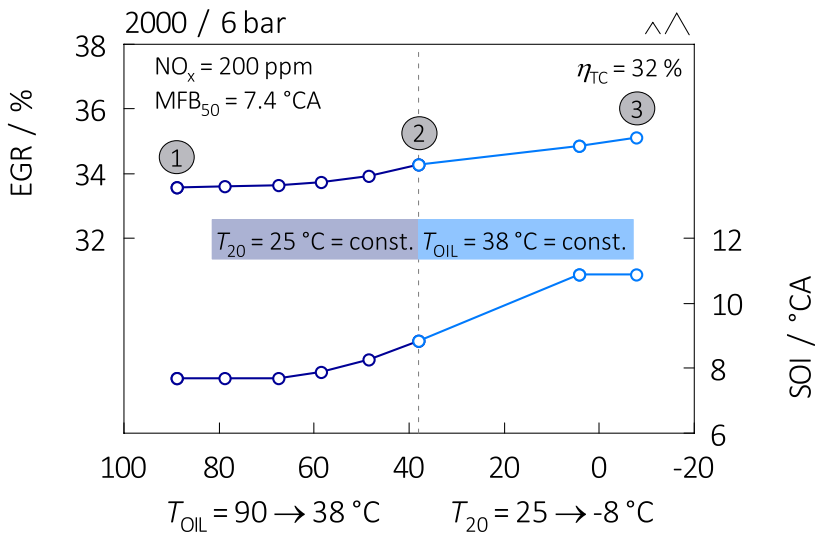

Fig. 8 Adjustment of the EGR rate and the SOI of the temperature variation at constant $\mathrm{NO}_{\mathrm{x}}$ emissions (with EGR)

Starting at an engine operation at $90^{\circ} \mathrm{C}($ (1) $)$, the coolant and lube oil temperatures are cooled down to about $40^{\circ} \mathrm{C}$ (2) at constant charge air temperature, while the FMEP is increased according to the formula in Fig. 4 causing a lower break thermal efficiency (BTE). Then, while keeping the coolant and oil temperature constant, the temperature after the charge air cooler $\mathrm{T}_{20}$ was decreased down to $-8^{\circ} \mathrm{C}$ (3) by regulating the coolant power of the refrigerating unit. The temperatures are lowered whilst maintaining the single pilot injection strategy of the hot engine without adaption 


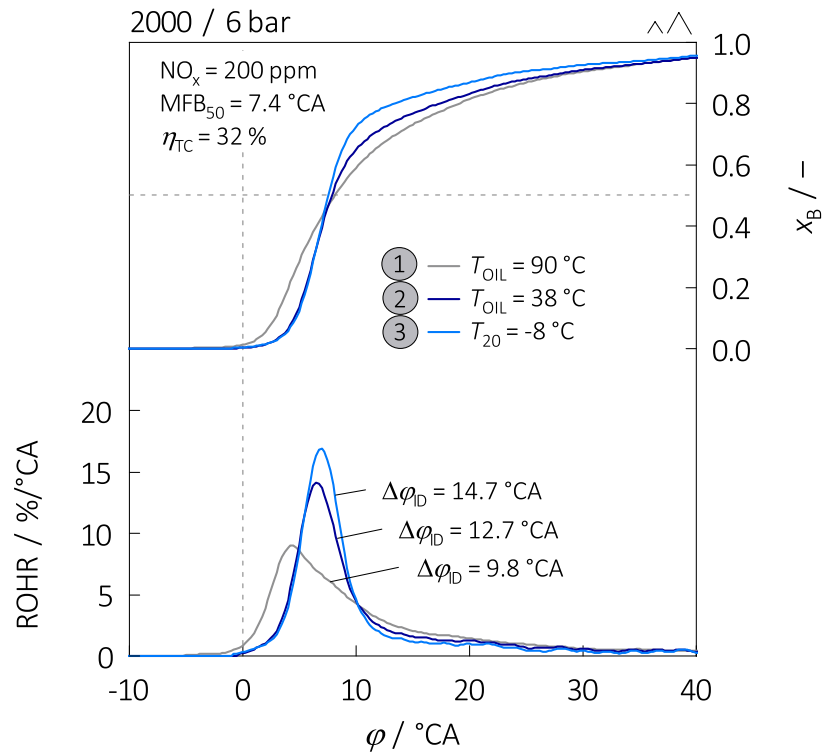

Fig. 9 Combustion analysis of different operation temperatures at constant $\mathrm{NO}_{\mathrm{x}}$ emissions (with EGR)

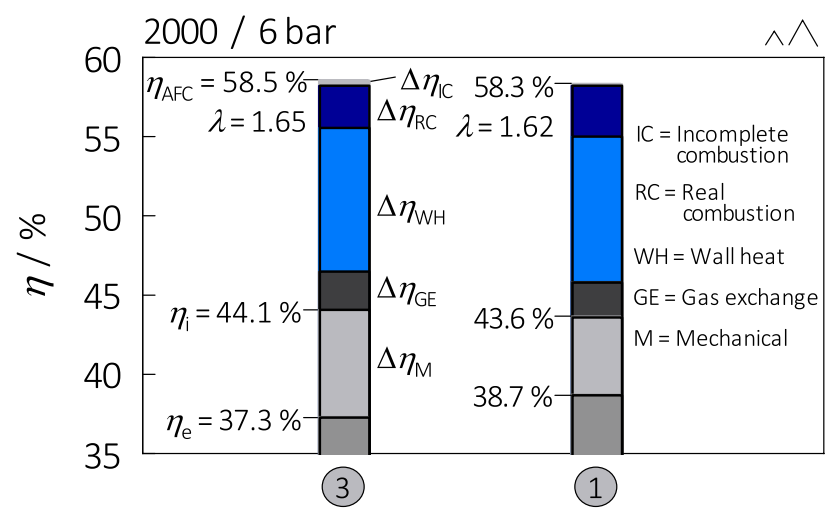

Fig. 10 Loss analysis of different operation temperatures at constant $\mathrm{NO}_{\mathrm{x}}$ emissions (with EGR)

(the injection strategy is indicated right above the diagram). Keeping the center of mass fraction burned $\left(\mathrm{MFB}_{50}\right)$ and the nitrogen oxide $\left(\mathrm{NO}_{\mathrm{x}}\right)$ emissions constant by adjusting the start of injection (SOI) and the EGR rate results in a longer ignition delay (ID), which leads in combination with a higher maximum rate of heat release (ROHR) to decreasing smoke, a rising combustion noise level (CNL) and a shorter combustion duration $\left(\mathrm{MFB}_{90-5}\right)$. It is assumed, that the lower maximum in-cylinder gas temperature causes a more incomplete combustion, resulting in higher carbon monoxide (CO) and FA emissions. The longer ID in cold operation supports the FA production due to the longer residence time for FA in low temperature [23].

The validation of the methodology shows the major challenges of emission optimization during cold run. The chosen methodology allows a steady state emission optimization, especially with respect to the products of the incomplete combustion, which increase in cold engine operation.

Figure 9 illustrates the cause of the increasing CNL with decreasing temperature. With the pilot injection strategy being not adapted and optimized, the longer ID leads to a combustion with a higher premixed combustion rate, resulting in a higher pressure gradient.

The efficiency difference between warm and cold engine operation based on a loss analysis according to Pischinger et al. [21] is depicted in Fig. 10. The higher charge air density in cold operation leads to a slight increase of the efficiency of the air fuel cycle with real cylinder charge. Higher unburned emissions result in a higher incomplete combustion loss. As a consequence of the shorter combustion duration, the real combustion loss is decreased. In cold operation, the wall heat loss is not increased due to the higher engine load, caused by the increase in FMEP. The lower exhaust gas temperature in cold operation results in a higher gas exchange loss. The mechanical loss shows the biggest change in cold run caused by the higher FMEP.

\section{Results}

In this section, the experimental results of the steady-state cold condition operation of the SCRE are pres-ented with an emphasis on the emission behavior.

\subsection{Pilot injection strategy optimization}

In cold operation, the pilot injection strategy becomes particularly important due to the longer ID resulting in a higher CNL, which can be counteracted by optimizing the pilot injection strategy.

As can be seen in Fig. 11, with single pilot injection a much higher pilot quantity is necessary in cold operation to achieve approximately the same pilot conversion than in warm operation. Nonetheless, due to the unfavorable ignition conditions in cold operation, the ROHR of the main injection rises sharply and causes a much higher CNL as in warm operation. A double pilot injection strategy with quite moderate injection quantities enables a combustion with a much lower CNL compared to single pilot injection, as also stated in [22]. The longer combustion duration with double pilot injection deteriorates the indicated engine efficiency compared to single pilot injection. Since CNL is given higher priority in the short period of cold operation than engine efficiency, the optimum double pilot injection strategy is discussed in the following.

For all results presented hereafter an uncooled EGR was applied bypassing the EGR cooler on the SCRE. Fig. 12 illustrates a pilot quantity sweep of a double pilot injection 

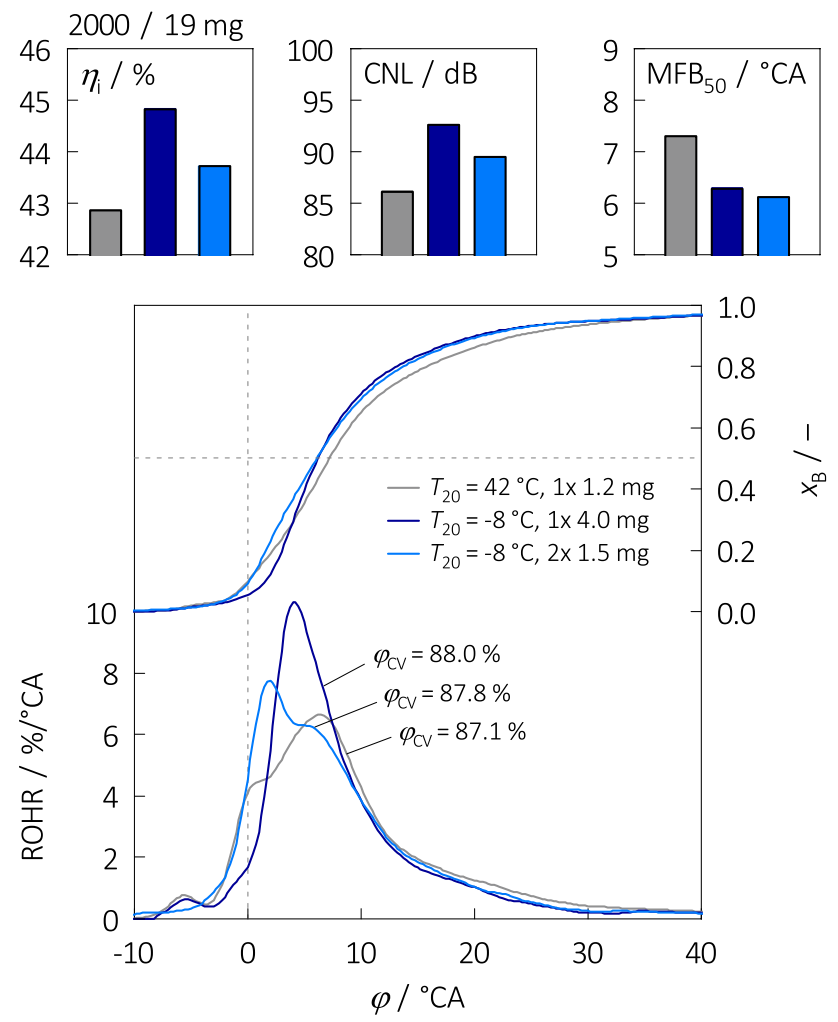

Fig. 11 Comparison of different pilot injection strategies without EGR in warm and in cold operation
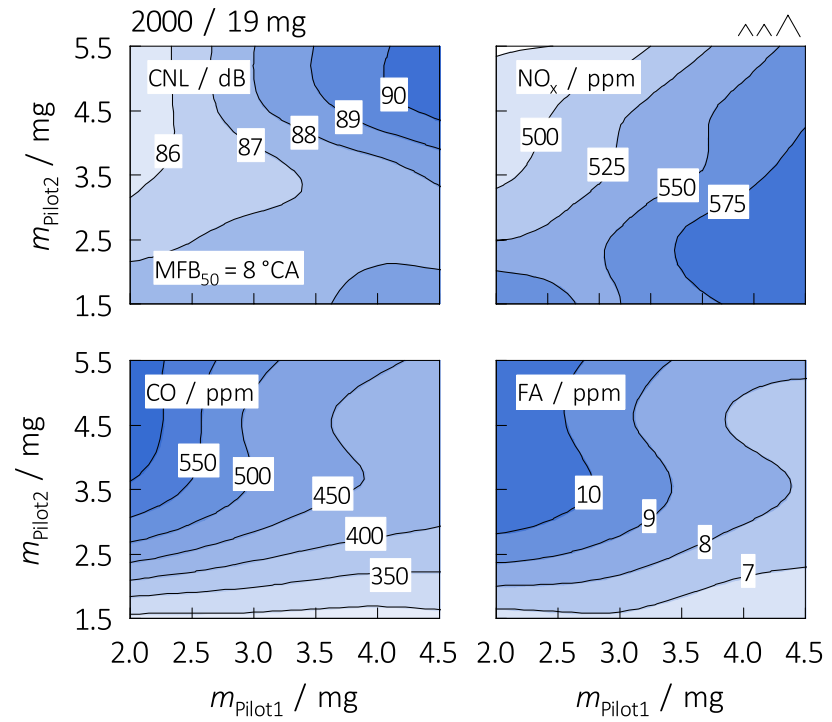

Fig. 12 Pilot injection quantity sweep without EGR in cold operation

strategy without EGR, at a constant $\mathrm{MFB}_{50}$, at a constant interval between the injection events and at constant total amount of fuel injected. The pilot injection quantity next to the main injection (pilot 1) is shown on the $\mathrm{x}$-axis and the further advanced pilot quantity (pilot 2) on the y-axis. The

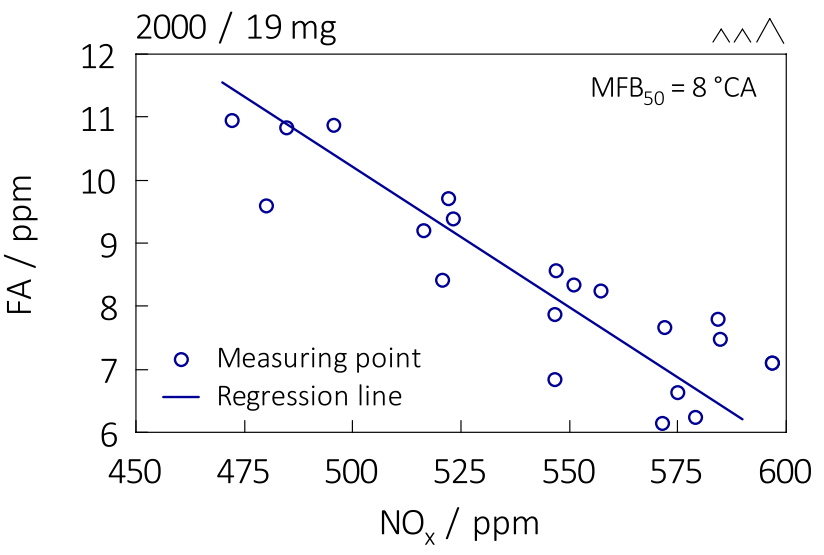

Fig. 13 Trade-off between FA and NOx emissions in cold operation

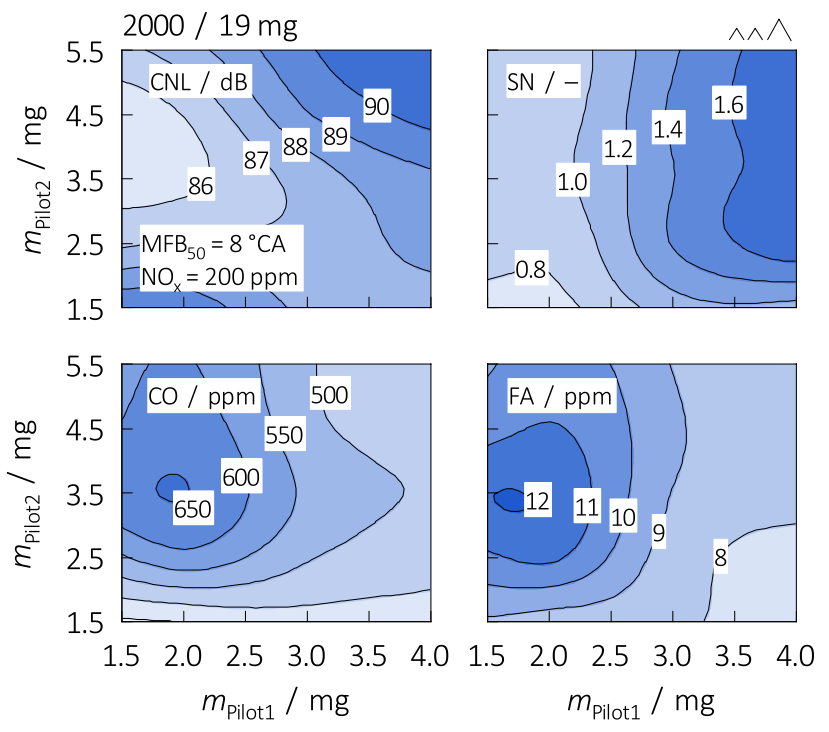

Fig. 14 Pilot injection quantity sweep at constant $\mathrm{NO}_{\mathrm{x}}$ emissions (with EGR) in cold operation

illustrated pilot amounts on the axes are the set values in the engine control unit. It can be observed, that a small pilot 1 in combination with a high pilot 2 quantity is favorable for a smooth cylinder pressure curve and thus low $\mathrm{NO}_{\mathrm{x}}$ and noise emissions. In contrast, this pilot strategy leads to the highest $\mathrm{CO}$ and FA emissions. Based on these meas-urements a trade-off between products of the incomplete combustion such as the FA emissions and the $\mathrm{NO}_{\mathrm{x}}$ emissions can be stated, as shown in Fig. 13. Since high $\mathrm{NO}_{\mathrm{x}}$ emissions are related to high local peak temperatures in the combustion chamber, this trade-off shows the thermal impact on unburned exhaust gas emissions. It can be concluded, that low local temperatures favour the generation of $\mathrm{CO}$ and FA. Chung et al. [23] stated for a DME flame that the low-temperature reaction previous to the diffusion flame promotes the FA formation. 
As depicted in Fig. 14, the double pilot injection quantities were also varied with EGR at constant target $\mathrm{NO}_{\mathrm{x}}$ emissions as well. A higher pilot 2 quantity leads to a shorter ID of the pilot 1 injection and higher rate of heat release of pilot 1. Consequently, the ID of the main injection decreases and the partly premixed combustion gets more pronounced. As can be seen in Fig. 14, the quantity of pilot 2 only has a slight influence on the smoke emissions. To achieve the same $\mathrm{NO}_{\mathrm{x}}$ emissions with a higher pilot 2 quantity, a lower EGR rate is necessary due to the decreasing maximum rate of heat release. As a consequence, the smoke emissions do not increase despite the shorter ID of the main injection and the higher total pilot fuel amount. In contrast to that a higher pilot 1 quantity, where nearly no decrease in maximum heat release rate is observed, leads to a shorter ID of the main injection and to higher smoke emissions. An early rise of the heat release, which can be caused by higher pilot 1 as well as too high pilot 2 quantities, leads to an increase of the combustion noise. Similar to the measurements without EGR a small pilot 1 quantity in combination with in this case $3.5-4.5 \mathrm{mg}$ of pilot 2 quantity results in the lowest noise, but quite high unburned emissions. From this conflicting emission trend behavior the FA-CNL trade-off can be derived, which is illustrated in Fig. 15. For the reasons of clarity only measurement points with medium pilot 1 quantities ( 2 and $3 \mathrm{mg}$ ) are used for generating the shown trade-off. It is assumed, that a high cylinder pressure rise, caused by a high initial combustion rate, leads to a more complete combustion. In addition, the FA-CNL-trade-off can be improved by an injector nozzle with an increased number of spray holes at a constant hydraulic flow rate due to the improved fuel atomization caused by the smaller nozzle hole diameter and hence improved mixture preparation.

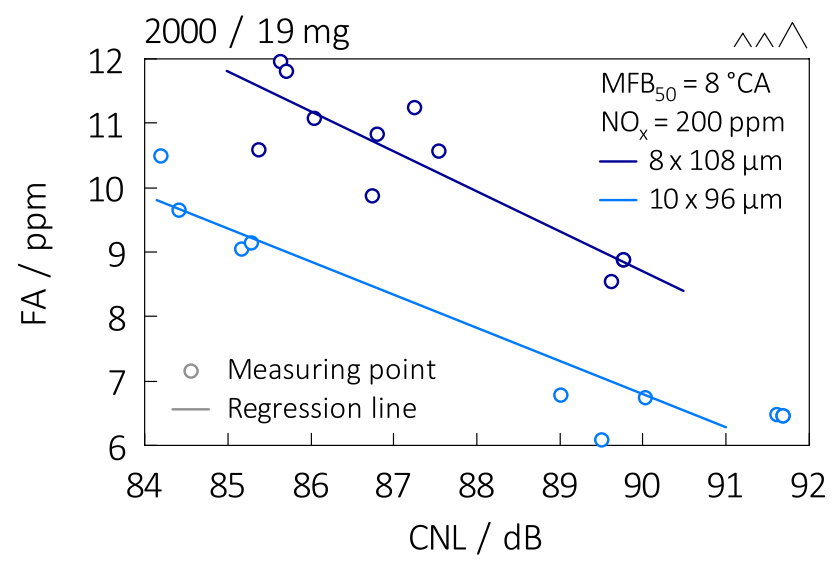

Fig. 15 Trade-off between FA und noise emissions at constant $\mathrm{NO}_{\mathrm{x}}$ emissions (with EGR) in cold operation

\subsection{Influence of swirl and rail pressure}

Both, swirl and rail pressure, have a large influence on the combustion process. Therefore, the influence of these two parameters in cold operation are compared to warm operation.

Figure 16 demonstrates a swirl sweep at a constant injection quantity and constant $\mathrm{NO}_{\mathrm{x}}$ emissions. In cold operation the lower charge air temperature leads to a higher indicated efficiency as a result of a shorter combustion duration and a higher excess air ratio (EAR). A higher swirl motion shortens the combustion duration and increases the wall heat and the pumping losses, as also reported by Olmeda et al. [24]. A maximum engine efficiency in this operation point can be found at a swirl number of 2.5 .

The double pilot injection strategy optimized for low smoke emissions in cold operation results in a slight increase in smoke emissions caused by the higher pilot quantities and less favorable ignition conditions compared to the warm operation with single pilot injection. With increasing swirl the smoke emissions get reduced due to a higher in-cylinder turbulence until a slight effect of over-swirling increases the smoke emissions again. However, the key-outcome shown in the diagram is that the trend as well as the optimum swirl level is the same for both operating conditions.

The rail pressure sweep in Fig. 17 displays also a similar rail pressure behavior for warm and cold operation. As a result of a higher rail pressure, the combustion noise increases due to a higher cylinder pressure gradient. The improved fuel atomization leads to lower smoke emissions.

\subsection{Influence of the injector nozzle hole number}

In addition to the discussed engine calibration effects, the injection equipment hardware for optimizing the cold emission behavior was investigated as well. The $\mathrm{MFB}_{50}$ of each

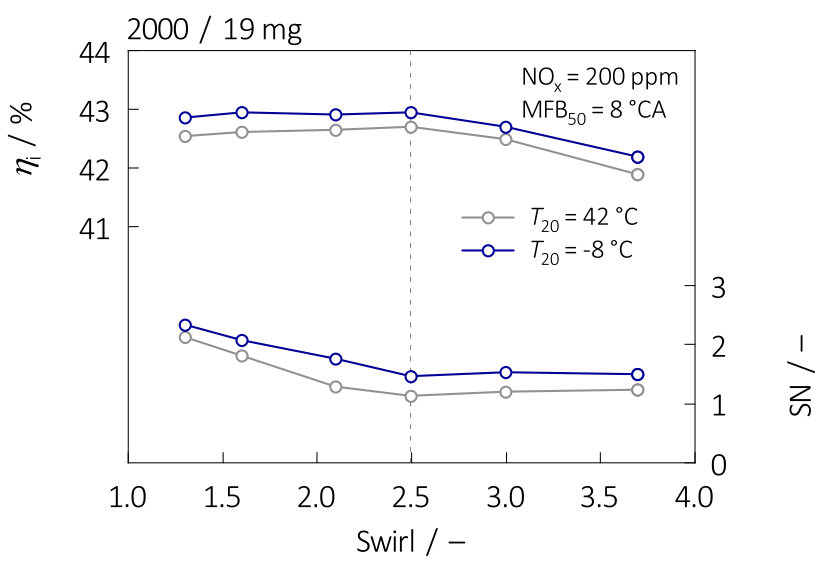

Fig. 16 Swirl sweep at constant $\mathrm{NO}_{\mathrm{x}}$ emissions (with EGR) in warm and in cold operation 


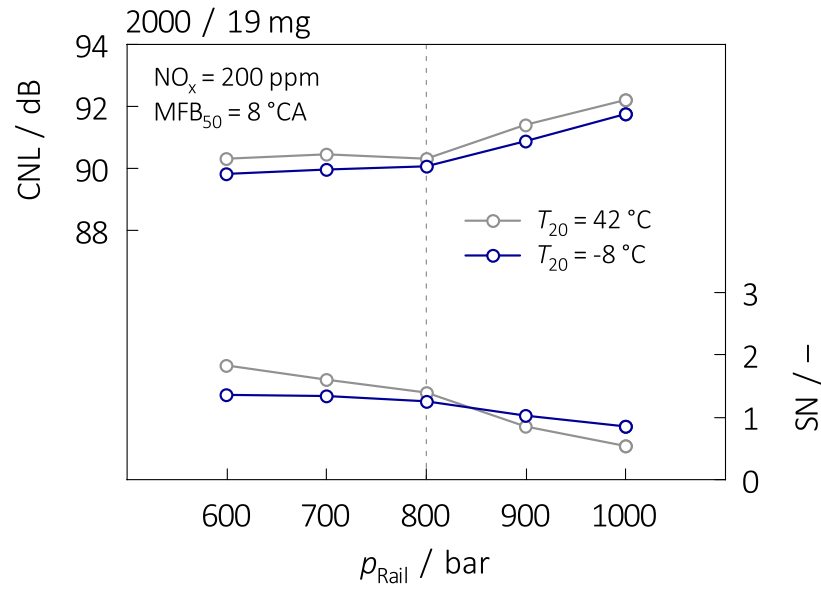

Fig. 17 Rail pressure sweep at constant $\mathrm{NO}_{\mathrm{x}}$ emissions (with EGR) in warm and in cold operation

following measurement changes by about the same amount along the EGR sweep, so the measurements can be compared at the same $\mathrm{NO}_{\mathrm{x}}$ emissions at approximately the same $\mathrm{MFB}_{50}$. For better comparability hereafter also for the warm engine operation a double pilot injection was developed. All following results were achieved with the for each nozzle design separately optimized double pilot injection strategy.

Figures 18 and 19 represent an EGR sweep in warm and in cold operation with double pilot injection strategy individually optimized for low smoke emissions.

Similar to the findings in Sect. 2.3, in Fig. 18 a lower BTE in cold operation due to the higher FMEP and a lower exhaust gas temperature caused by the low charge air temperature can be seen. An injector with an increased number of nozzle holes does not affect the BTE significantly. Only a slight deterioration of the indicated efficiency was found, which may be caused by the lower jet momentum resulting in a less deep penetration of the injection jets. The exhaust

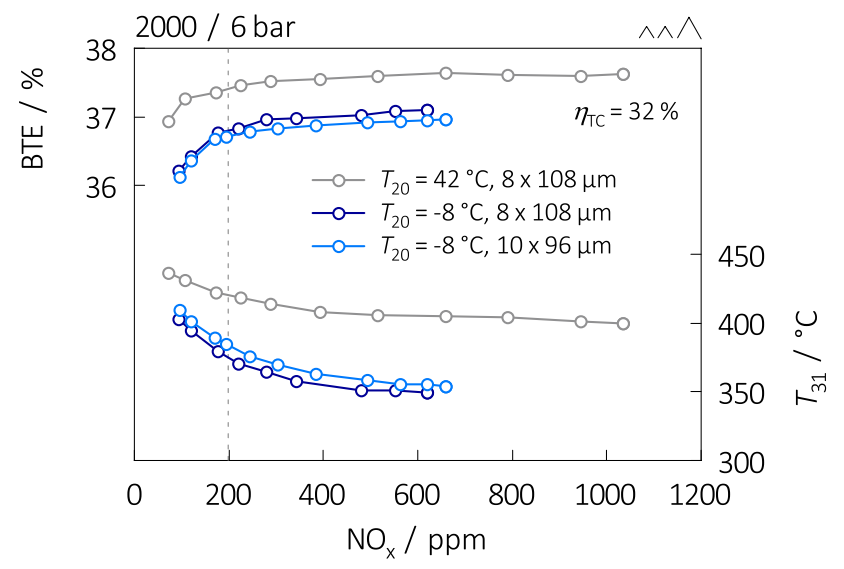

Fig. 18 Combustion parameters for different injector nozzle hole numbers in warm and in cold operation

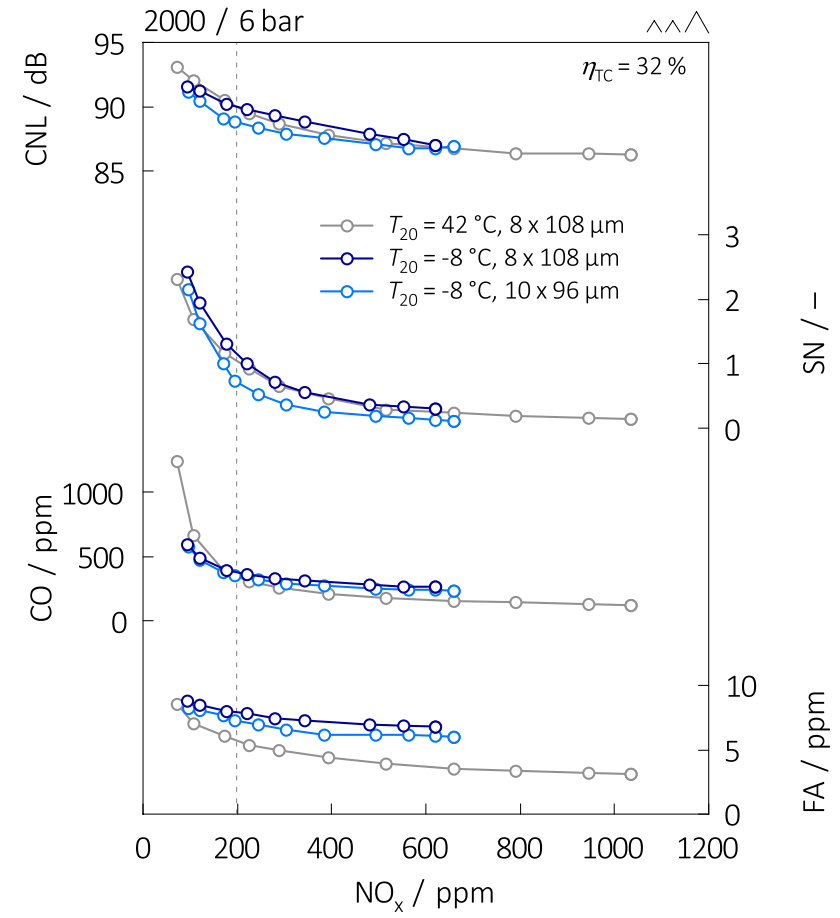

Fig. 19 Emission behavior for different injector nozzle hole numbers in warm and in cold operation

gas temperature $\left(T_{31}\right)$ rises as a result of the lower efficiency at approximately the same combustion duration.

Figure 19 shows that with double pilot strategy a simi-lar combustion noise can be realized in cold operation, but using the same nozzle hole number, the $\mathrm{NO}_{\mathrm{x}}$-smoke trade-off at high EGR rates is slightly deteriorated in cold operation despite lower $\mathrm{NO}_{\mathrm{x}}$ emissions without EGR. The higher IMEP and thus higher fuel injected may cause the increase of smoke emission. Furthermore it is assumed, that the lower in-cylinder temperatures in cold operation lead to a more incomplete combustion, which manifests itself in higher $\mathrm{CO}$ and FA emissions.

The better fuel atomization and an improved mixture preparation with a higher number of smaller nozzle holes cause an improved $\mathrm{NO}_{\mathrm{x}}$-smoke trade-off and lower FA emissions. Additionally, the less steep rise of the ROHR results in an improved combustion noise. Consequently, this nozzle improves both, the FA-NO ${ }_{\mathrm{x}}$ and the FA-CNL trade-off in cold operation.

\subsection{Influence of the injector nozzle hole diameter}

Since the previous measure that having been researched lead to an improvement of the cold emissions, the influence of a larger hole diameter and, therefore, a higher jet momentum at a constant number of nozzle holes was investigated.

Figure 20 depicts the results with the larger nozzle hole diameter for which also an individually optimized double pilot strategy for low smoke emissions was used. The higher hydraulic injector flow rate leads to a higher maximum 


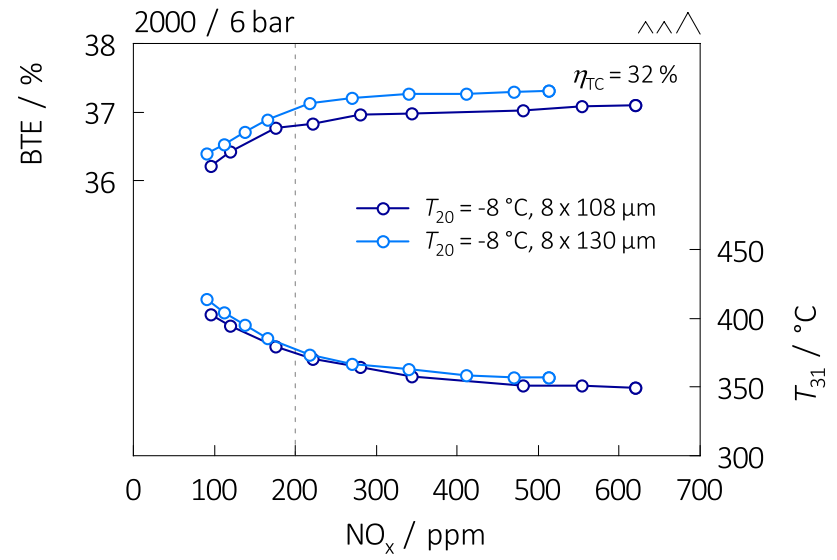

Fig. 20 Combustion parameters for different injector nozzle hole diameters in cold operation

ROHR and a later rise of the cylinder pressure at the same $\mathrm{MFB}_{50}$, which results in lower $\mathrm{NO}_{\mathrm{x}}$ emissions without EGR. Consequently, the lower EGR rates required for lowering $\mathrm{NO}_{\mathrm{x}}$ emissions may contribute to improve BTE. The exhaust gas temperature is slightly increased because of a longer burn-out phase, which may be a result of a deteriorated initial fuel preparation as well as wall impingement. The ROHR shows a delayed combustion during the burn-out phase, which supports the assumption of a different flame-wall interaction with a larger hole diameter as well as a worse fuel atomization which also leads to higher unburned exhaust gas emissions, as can be seen in Fig. 21. On the one hand the higher maximum ROHR improves the $\mathrm{NO}_{\mathrm{x}}$-smoke trade off, but on the other hand the higher pressure gradient increases the CNL. As this nozzle design deteriorates, the FA- $\mathrm{NO}_{\mathrm{x}}$ and the FA-CNL trade-off, it does not represent an improvement of the cold emission behavior. Moreover, normally this measure is also known to be detrimental to the emission behavior at standard operating conditions.

\subsection{Emissions of an alternative fuel}

With the best nozzle design found in the afore shown research, the cold emissions of the alternative fuel called Blend-3, which could be a possible replacement of diesel in the future, was investigated. The double pilot injection strategy was optimized for a low CNL with diesel and adjusted for Blend-3 to compare the fuels at approximately the same $\mathrm{CNL}$. The fuel properties of the tertiary blend $\left(58 \% \%_{\mathrm{v} / \mathrm{v}} \mathrm{HVO}\right.$, $30 \%_{\mathrm{v} / \mathrm{v}} 1$-Octanol and $\left.12 \%_{\mathrm{v} / \mathrm{v}} \mathrm{OME}_{2-5}\right)$ are stated in Table 3.

As shown in Fig. 22, the efficiency decreases with Blend-3 due to higher wall heat losses, which was found by the loss analysis. It is assumed, that the oxygen content in the fuel leads to a higher combustion temperature due to a higher oxygen to inert gas ratio, resulting in higher $\mathrm{NO}_{\mathrm{x}}$ emissions without EGR but also in higher thermal losses. Despite the lower efficiency the tertiary blend reduces the $\mathrm{CO}_{2}$ engine-out emissions due to the lower $\mathrm{CO}_{2}$ factor of the fuel. The slightly shorter combustion duration leads to the decrease of the exhaust gas temperature.

Figure 23 displays the great advantage of this alternative fuel: At about the same noise emissions the $\mathrm{NO}_{\mathrm{x}}$-smoke

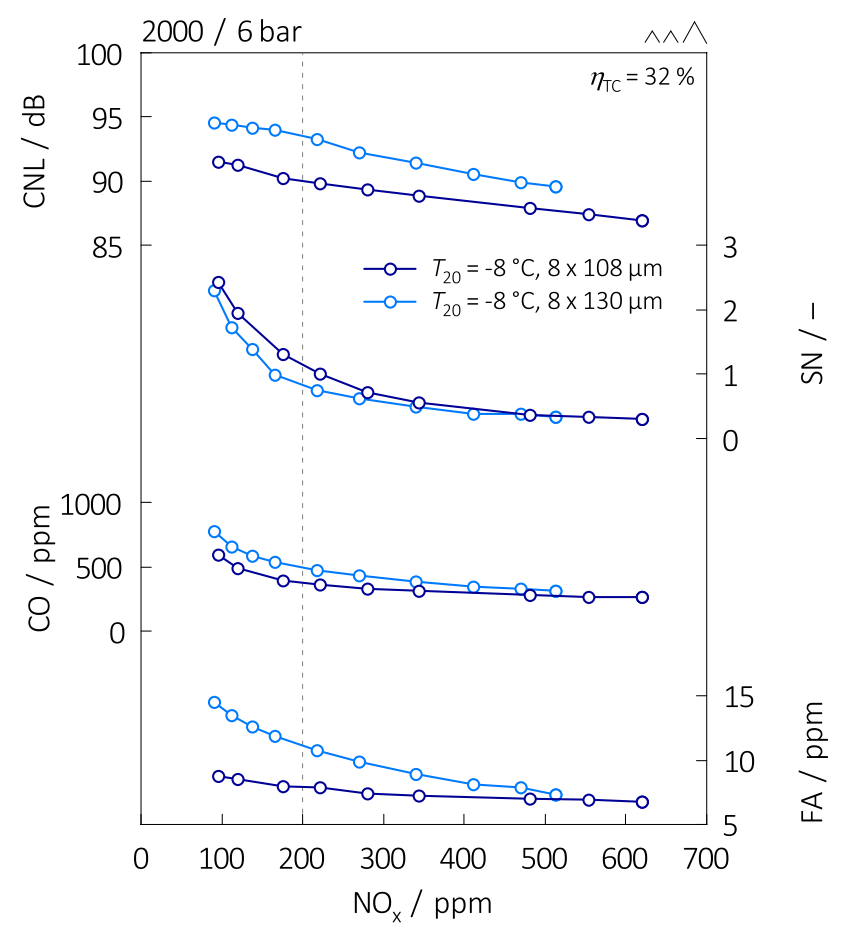

Fig. 21 Emission behavior for different injector nozzle hole diameters in cold operation

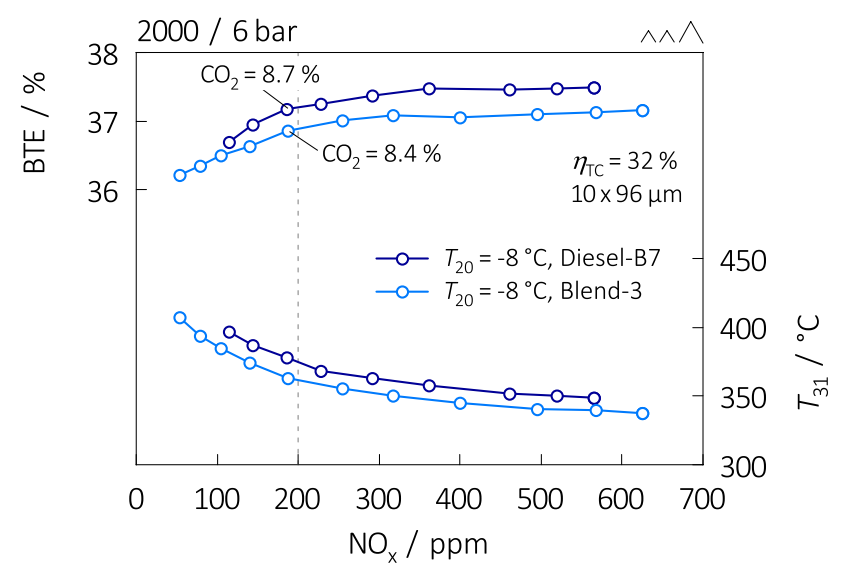

Fig. 22 Combustion parameters for commercial diesel and an alternative fuel in cold operation 


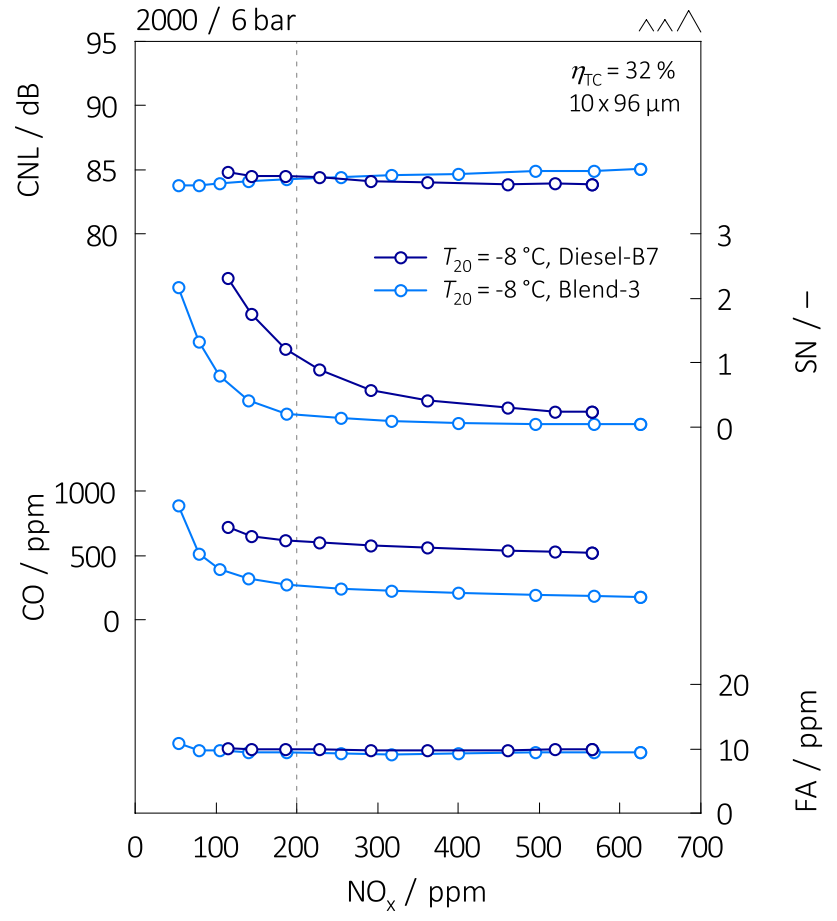

Fig. 23 Emission behavior for commercial diesel and an alternative fuel in cold operation

trade-off is significantly improved. The oxygen content of the fuel and consequently higher EAR reduce smoke emissions. This also enables the application of higher EGR rates to reduce $\mathrm{NO}_{\mathrm{x}}$ emissions despite the higher $\mathrm{NO}_{\mathrm{x}}$ emissions generated at the starting point without EGR. Furthermore, the more complete combustion with Blend-3 causes a reduction of the $\mathrm{CO}$ and $\mathrm{FA}$ emissions as well. These findings prove, that an oxygen-containing fuel significantly improves the $\mathrm{NO}_{\mathrm{x}}$-smoke trade-off as well as the other trade-offs being important in cold operation. Therefore, this blend has a great potential for raw and $\mathrm{CO}_{2}$ emission reduction.

\section{Conclusion and outlook}

The present study investigates potential engine meas-ures to optimize the emission behavior during cold engine operation of a CI engine with diesel and an alternative fuel. The motivation for this experimental work is the raw emission reduction in the time between the engine start and the exhaust aftertreatment system reaching the light-off temperature. To investigate this research topic, a large number of test runs on an SCRE were carried out under steady-state cold conditions with a charge air temperature of down to $-8^{\circ} \mathrm{C}$ and a coolant and lube oil temperature of about $38^{\circ} \mathrm{C}$. For emulating a full engine behavior, higher friction in cold operation was taken into account and the exhaust pressure was adjusted according to the turbocharger equation. Special attention was paid to some currently still non-regulated pollutant emissions like carbonyls.

As the results show, without application optimization in cold engine operation, the lower in-cylinder temperatures cause a longer ID, thus a higher CNL, higher unburned emissions like CO and FA and a decreased BTE. An optimized double pilot injection strategy allows to achieve the same combustion noise in warm and in cold operation. In cold operation FA-NO ${ }_{\mathrm{x}}$ and FA-CNL trade-offs exist, which can be improved using a nozzle with an increased number of nozzle holes at the same flow rate. A larger hole diameter and therefore higher hydraulic flow rate deteriorates these cold operation trade-offs. The swirl and the rail pressure behavior are the same for both operating conditions. Investigations of an alternative, oxygen-containing fuel resulted, besides the improvement of the cold trade-offs, in a remarkable smoke reduction, which enables higher EGR rates and thus lower $\mathrm{NO}_{\mathrm{x}}$ engine-out emissions during the early driving phases when the EAS is not yet warmed-up and thus working efficiently.

This work shows the existence of further engine optimization potential in cold operation. Especially alternative fuels which might play an important role in the defossilization of transportation should be further investigated.

The research work was complemented with tests on a 4-cylinder engine to confirm the proper behavior of an EU7 capable EAS under these cold conditions. These results confirmed the emission trends investigated and optimized on the SCRE.

\section{Appendix}

See Tables 2, 3 .

Table 2 Diesel injector nozzle designs

\begin{tabular}{lll}
\hline Abbrevation & Hole number $\times$ diameter & Flow rate \\
\hline $8 \times 108$ & $8 \times 108 \mu \mathrm{m}$ & $620 \mathrm{ml} / \mathrm{min}$ \\
$10 \times 96$ & $10 \times 96 \mu \mathrm{m}$ & $620 \mathrm{ml} / \mathrm{min}$ \\
$8 \times 130$ & $8 \times 130 \mu \mathrm{m}$ & $900 \mathrm{ml} / \mathrm{min}$ \\
\hline
\end{tabular}


Table 3 Fuel properties

\begin{tabular}{llll}
\hline Fuel property & Unit & Diesel-B7 & Blend-3 \\
\hline Cetane number & - & 52.0 & 61.5 \\
Density at $15^{\circ} \mathrm{C}$ & $\mathrm{kg} / \mathrm{m}^{3}$ & 838.7 & 824.7 \\
Lower Heating Value & $\mathrm{MJ} / \mathrm{kg}$ & 42.66 & 38.72 \\
$\mathrm{H} / \mathrm{C}$ Ratio & - & 1.89 & 2.22 \\
Stoichiometric Air Demand & $\mathrm{kg} / \mathrm{kg}$ & 14.52 & 12.99 \\
Carbon content & $\%$ & 85.9 & 75.0 \\
Hydrogen content & $\%$ & 13.6 & 14.0 \\
Oxygen content & $\%$ & 0.9 & 10.7 \\
Total aromatics content & $\%$ & 19.9 & 0.2 \\
Viscosity at $40^{\circ} \mathrm{C}$ & $\mathrm{mm}{ }^{2} / \mathrm{s}$ & 2.80 & 2.58 \\
Flash point $^{\circ}$ & ${ }^{\circ} \mathrm{C}$ & 67 & 71 \\
$\mathrm{~T}_{10}$ & ${ }^{\circ} \mathrm{C}$ & 207.2 & 188.4 \\
$\mathrm{~T}_{50}$ & ${ }^{\circ} \mathrm{C}$ & 274.4 & 234.7 \\
$\mathrm{~T}_{90}$ & ${ }^{\circ} \mathrm{C}$ & 338.1 & 287.5 \\
$\mathrm{CO}_{2}$ Factor & $\mathrm{g} / \mathrm{MJ}$ & 73.8 & 71.0 \\
\hline
\end{tabular}

Acknowledgements This research work is part of the research project "RC-LowCAP", a publicly funded project by the Austrian Research Promotion Agency (FFG) with industry partners AVL, OMV (Downstream), Vitesco Technologies Emitec and Heraeus.

Funding Open access funding provided by Graz University of Technology.

Open Access This article is licensed under a Creative Commons Attribution 4.0 International License, which permits use, sharing, adaptation, distribution and reproduction in any medium or format, as long as you give appropriate credit to the original author(s) and the source, provide a link to the Creative Commons licence, and indicate if changes were made. The images or other third party material in this article are included in the article's Creative Commons licence, unless indicated otherwise in a credit line to the material. If material is not included in the article's Creative Commons licence and your intended use is not permitted by statutory regulation or exceeds the permitted use, you will need to obtain permission directly from the copyright holder. To view a copy of this licence, visit http://creativecommons.org/licenses/by/4.0/.

\section{References}

1. Commission Regulation (EU) 2016/427.: Off. J. Eur. Union L 82, (2016)

2. Commission Regulation (EU) 2019/631.: Off. J. Eur. Union L 111, (2019)

3. Bielaczyc, P., Woodburn, J., Szczotka, A.: An Investigation into cold start emissions from compression ignition engines using EU legislative emissions test procedures. SAE Int. J. Fuels Lubr. (2013). https://doi.org/10.4271/2013-01-1304

4. Liu, D., Xu, H., Tian, J., Tan, C.: Cold and warm start characteristics using $\mathrm{HVO}$ and RME blends in a V6 diesel engine. SAE Int. J. Fuels Lubr. (2013). https://doi.org/10.4271/2013-01-1306

5. Ramadhas, A., Xu, H.: Influence of coolant temperature on cold start performance of diesel passenger car in cold environment. SAE Technical Paper 2016-28-0142 (2016) https://doi.org/10. 4271/2016-28-0142
6. Ratzberger, R., Kraxner, T., Pramhas, J., Hadl, K., Eichlseder, H., Buergler, L.: Evaluation of valve train variability in diesel engines. SAE Int. J. Engines (2015). https://doi.org/10.4271/ 2015-24-2532

7. Pedrozo, V.B., May, I., Lanzanova, T.D.M., Zhao, H.: Potential of internal EGR and throttled operation for low load extension of ethanol-diesel dual-fuel reactivity controlled compression ignition combustion on a heavy-duty engine. Fuel. (2016). https://doi.org/ 10.1016/j.fuel.2016.03.090

8. Roberts, A., Brooks, R., Shipway, P.: Internal combustion engine cold-start efficiency: a review of the problem, causes and potential solutions. Energy Convers. Manag. (2014). https://doi.org/10. 1016/j.enconman.2014.03.002

9. Hofstetter, J., Boucharel, P., Atzler, F., Wachtmeister, G.: SAE Int. J. Adv. Curr. Prac. Mobil. (2021). https://doi.org/10.4271/ 2020-37-0017

10. Zubel, M., Pischinger, S., Heuser, B.: Assessment of the full thermodynamic potential of C8-oxygenates for clean diesel combustion. SAE Int. J. Fuels Lubr. (2017). https://doi.org/10.4271/ 2017-24-0118

11. Zubel, M., Bhardwaj, O.P., Heuser, B., Holderbaum, B., Doerr, S., Nuottim, J.: Advanced fuel formulation approach using blends of paraffinic and oxygenated biofuels: analysis of emission reduction potential in a high efficiency diesel combustion system. SAE Technical Paper 2016-01-2179 (2016) https://doi.org/10.4271/ 2016-01-2179

12. Heuser, B., Kremer, F., Pischinger, S., Julis, J., Leitner, W.: Optimization of diesel combustion and emissions with newly derived biogenic alcohols. SAE Technical Paper 2013-01-2690 (2013) https://doi.org/10.4271/2013-01-2690

13. Richter, G., Zellbeck, H.: OME als Kraftstoffersatz im PkwDieselmotor. MTZ Motortech Z (2017). https://doi.org/10.1007/ s35146-017-0131-y

14. Pellegrini, L., Marchionna, M., Patrini, R., Beatrice, C., Del Giacomo, N., Guido, C.: Combustion Behaviour and Emission Performance of Neat and Blended Polyoxymethylene Dimethyl Ethers in a Light-Duty Diesel Engine. SAE Technical Paper 201201-1053 (2012) https://doi.org/10.4271/2012-01-1053

15. Pelerin, D., Gaukel, K., Hartl, M., Wachtmeister, G.: Nitrogen oxide reduction potentials using dimethyl ether and oxymethylene ether in a heavy-duty diesel engine. SAE Technical Paper 202001-5084 (2020) https://doi.org/10.4271/2020-01-5084

16. Aatola, H., Larmi, M., Sarjovaara, T., Mikkonen, S.: Hydrotreated Vegetable Oil (HVO) as a renewable diesel fuel: trade-off between $\mathrm{NO}_{\mathrm{x}}$, particulate emission, and fuel consumption of a heavy duty engine. SAE Technical Paper 2008-01-2500 (2008) https://doi. org/10.4271/2008-01-2500

17. Sugiyama, K., Goto, I., Kitano, K., Mogi, K., Honkanen, M.: Effects of Hydrotreated Vegetable Oil (HVO) as renewable diesel fuel on combustion and exhaust emissions in diesel engine. SAE Int. J. Fuels Lubr. (2012). https://doi.org/10.4271/2011-01-1954

18. Wu, Y., Ferns, J., Li, H., Andrews, G.: Investigation of combustion and emission performance of hydrogenated vegetable oil (HVO) diesel. SAE Int. J. Fuels Lubr. (2017). https://doi.org/10.4271/ 2017-01-2400

19. Pellegrini, L., Beatrice, C., Di Blasio, G.: Investigation of the effect of compression ratio on the combustion behavior and emission performance of hvo blended diesel fuels in a single-cylinder light-duty diesel engine. SAE Technical Paper 2015-01-0898 (2015) https://doi.org/10.4271/2015-01-0898

20. Merker, G., Schwarz, C., Stiesch, G., Otto, F.: Verbrennungsmotoren, Simulation der Verbrennung und Schadstoffbildung. Vieweg+Teubner Verlag, 3. Auflage, Wiesbaden (2006) https:// doi.org/10.1007/978-3-8351-9069-6

21. Pischinger, R., Klell, M., Sams, T.: Thermodynamik der Verbrennungskraftmaschine, pp. 315-317. Springer, Wien (2009) 
22. Yanai, T., Aversa, C., Dev, S., Reader, G., Zheng, M.: Investigation of fuel injection strategies for direct injection of neat $\mathrm{n}$-butanol in a compression ignition engine. SAE Int. J. Engines (2016). https://doi.org/10.4271/2016-01-0724

23. Chung, K., Zhu, X., Moiz, A., Lee, S., De Ojeda, W.: Characteristics of formaldehyde (CH2O) formation in dimethyl ether (DME) spray combustion using PLIF imaging. SAE Int. J. Fuels Lubr. (2016). https://doi.org/10.4271/2016-01-0864

24. Olmeda, P., Martin, J., Garcia, A., Villalta, D., Warey, A., Domenech, V.: A combination of swirl ratio and injection strategy to increase engine efficiency. SAE Int. J. Engines (2017). https://doi. org/10.4271/2017-01-0722
25. ÖNORM EN590:2019-08-01: Automotive fuels-DieselRequirements and test methods. Austrian Standards International, Vienna (2019)

Publisher's Note Springer Nature remains neutral with regard to jurisdictional claims in published maps and institutional affiliations. 